\title{
Evaluation of the Factors influencing the Indigenous Software Products Development in Nigeria.
}

\author{
G.O. Binuyo, T.O. Oyebisi, A. Olayinka and B.S Afolabi \\ African Institute for Science Policy and Innovation, Department of Computer Science and Engineering, Obafemi
}

Awolowo University

\begin{abstract}
This paper evaluate the internal and external factors influencing software development in Nigeria. The significance of these factors were also examined and the level of acceptability of the locally developed software products. The ICT firms that specialized in software development, educational institutions and other major stakeholders, including users of software packages were also covered.

Data were collected using sets of questionnaire and from secondary sources. The questionnaire was administered on purposively selected software developers in select ICT firms and elicited information on factors influencing the indigenous software product development in Nigeria. A five-point Likert scale rating of 5 to 1 was used to determine the relative weight of the influencing variables. The result indicated the internal factors influencing software development were human resources (3.69), on the job training (3.58), R\&D activities (3.48) and working experience (3.37). While access to technical information and support (3.65), competition with international market (3.59), economic factor (3.46), access to professional skill from the labour market (3.39) were the external factors that influence software development in Nigeria with significant difference $F=8.60 p \leq 0.05$. Acceptability of locally developed software in Nigeria, was on the average, relatively low compared with the foreign software products. This was due to the problem of reliability, efficiency, security and scope of functionality. These were circumstances that made users prefer foreign software products. Similarly, the result revealed that the desirable and critical role of government support and policy to drive the software industry for growth were lacking. This imply the need for effective policy framework for the development of software in the short, mid and long term prognosis within the earlier opportunity niches and should be accorded the desirable national attention and priority.
\end{abstract}

Keywords: Software Development, software products, software users/stakeholders, Indigenous, Nigeria.

\section{Introduction}

The computer software has become a leading source of employment creation and economic growth in the world [19]. The industry is also a critical factor in knowledge production that is embodied in its products and services. Although the computer software industry is dominated by the firms based in major industrialized countries of the world, it continues to offer great prospects for economic growth and industrial development within developing economics.

Similarly, software has become a key facilitating technology making it a major strategic technology choice for growth and development. It underpin the actual creation and efficient utilization of core aspects of modern services and manufacturing of physical products [6]. The current globalization of markets and the knowledge intensive nature of software has made the sector to become one of the most internationally dispersed high-tech industry and an increasingly important complex component, desirable for growth and development, in any economy [25][1]. Furthermore, the unique way software knowledge is generated and traded in the industry has made intellectual property protection to form a fundamental element of how the sector has grown and developed.

The situation in Nigeria as revealed by the study confirmed that a total of about $30 \%$ of the software products running in the Nigerian market are indigenous software developed locally. While foreign software products are still dominant with about $70 \%$ market shares. This indigenous software include among others, software developed by Chams Nigeria Limited for Visitors' lodges used by the Hotels Industry. This is a solution software for taking inventory of visitors, capture images and biometric information; software for election data collection; the electronics identification data (IED) software for data collection of residents in Osun state. Other indigenous software products are "Please to meet you" (PZMU) software- A social marketing tool/solution developed by IQube Labs. All these indigenous software products are respectively enjoying $100 \%, 80 \% \quad 60 \%$, and $70 \%$ acceptability and patronages across the Nigerian software users and market. (Appendix I). In spite of this high level of patronage and acceptability of indigenous software products, their share of Nigerian market is still low at about $30 \%$ compared with about $70 \%$ of market domination by foreign software products. However, the circumstances of the intellectual property protections of these indigenous software products is a significant and important issue that this study did not cover but still need to be investigated. The high growth rate of this sector had resulted in dramatic increase in the spread of software products and services world-wide with a tremendous high level of productivity [12].

It was also observed through this study, that the advent of ICT and software revolution presents Nigeria with an opportunity to take a prominent, if not high-up position in the global ICT value chain. The value chain consists of the creators, distributors, resellers and consumers. Nigeria is Africa's busiest ICT market because of the trading, imposing and consumption in ICT. However, these alone are not strengths in the new knowledge-economy. The software opportunities can unleash the potential of the Nigerian nation. With large, youthful, educated and enterprising populace, software provides Nigeria with a unique opportunity niches to diversify Nigerian economy from commerce-dominated nature to high-tech knowledge economy. This is more so that the success of a nation's economy depends on the productivity and the extent of its Research and 
Development (R\&D) activities. It was reported in [17] that $70 \%$ of the product development costs are now in software development. It was further estimated that, softwarebased product functionality is a relatively new phenomenon and there is every indication that it will continue to grow rapidly, in the amount of software and in its complexity. Consequently, the nations that invest heavily in R\&D for software development are expected to predominantly have an in-flow of international payments for technology such as patent royalties and payments for technical assistance, services and expertise. Also, nations that demonstrate the highest innovative performance and investment, and that have necessary infrastructure for Software development and acquisition are most likely to come with new opportunities that could further improve their technological position in the world [27].

It is for the foregoing reasons that governments, all over the world struggle with the problem of how to ensure that Science and Technology contribute effectively to solving national problems [5]. It is important to understand that software development is the significant engine for R\&D organizations and their effective roles in the society. Software development therefore signify and reflects the ability to respond rapidly through changes in products and processes and also the ability for innovation, which is a flow variable that could provide the desirable cutting edge in competing with developed countries and bring about comparative advantage in the sector [24].

This study therefore evaluated the factors influencing indigenous software development in Nigeria that could culminate into technological capability leading to competitiveness and growth of the software sector. The empirical analyses generated by this research and the practical recommendations that emerged from it would serve as key sources of base data for software developers, corporate managers, government policy and decision makers to design and implement strategies to speed up development in developing countries' software sector.

\section{Related Work}

Software development is the production or creation of software. This software could be produced for a variety of purposes for meeting specific needs of a specific client/business; perceived need of some set of potential users; for personal use and increasing market competition [14].

Software development is defined in [26] as the activity that involves process of writing and maintaining the source code, and in the broader sense, the term includes all that is involved between the conceptions of the desired software through to its final manifestation. Therefore, software development may include research, new development, modification, reuse, re-engineering, maintenance, or any other activity that results in software products [4]. Moreover, as a nascent Industry and fastchanging technology, market forces alone are often inadequate to harness the software industry potentials and it has therefore become particularly important to focus on the dynamic nature of the public services and social priorities and to serve the needs of the poor, rural areas, small and medium enterprises (SMEs and nongovernmental organizations (NGOs) who are also part of the stakeholders and critical elements needed to drive a robust knowledge economy.
The foregoing fundamental change to development is a result of a number of factors, including the increasing reliance on technology, the need to adapt to changing market place demands, the issue of maintenance and integrating legacy systems along with a growing requirement for effective management of IT. These issues are the driving force for the extinction of monolithic software systems [29]. The notion of monolithic system is being replaced by the creation of modularized, loosely coupled parts and components that can be re-used and readily integrated across applications. This relatively new and growing requirement for componentization of software is impacting the nature of the global software development industry as it evolves into a manufacturing industry.

III. Factors influencing Software Development The factors influencing software development and the institutional frameworks that promotes its programmes and projects can be grouped into two categories. These are the internal and external factors $[10$, $11,19]$.

\section{(a) Internal factors}

(i) Human resources: This encompass the skills and experience of top/middle management and production workers, education level of staff and regular trainings, collaboration between company's employees, costs of labour, motivation of a personnel to better performance and increased productivity and the rate of staff turnover.

(ii) Products / Services: This consists of the competitive features of a product/service, its quality, extra services related to a product (guarantee service, free installation, etc), delivery term and quality, technological innovations used in production processes, pricing options offered to customers.

(iii) Company-related: This entails timing for market, sales trends, company's reputation and image, brand perception, location (in terms of proximity to local markets, distribution channels, development of infrastructure and communications), resource base (price and quality of resources, proximity to resource supply), government support, quality of suppliers, flexibility and responsiveness to market changes, profitability rates, company's expansion potential.

$\begin{array}{ll}\text { (b) } & \text { External factors } \\ \text { (i) } & \text { Market environment: It depicts the level and }\end{array}$ intensity of competition (number of competitors, their scale, recognition and experience on market), market trends (growth of customers, companies, sales, etc), and innovations by competitors (whether the competitors produce or sell traditional or hi-tech modern products or services), market entry barriers (control of resources, large initial investments, government policy, etc).

(ii) Economic factors: It covers inflation rate, income growth, general taxation burden and taxes imposed on target product/service category, exchange rate, trade barriers (for international traders), access to loans (availability and costs of fund/credits), unemployment rate and influence of weather or seasonality. The government fiscal and monetary policies are also critical factors of influence.

(iii) Social factors: This shows the demographic trends (population growth), lifestyle trends, consumer attitudes, ethnic/religious influence, media market development, age distribution (percentage of audience 
with target age group), healthcare protection (development of healthcare services), education level, labour mobility, social legislation and government support.

(iv) Technological factors: The component include IT development, technology transfer, legislation (laws and directions on technology processes, intellectual property protection, patenting, licensing, etc), communication sector growth (broadband internet coverage, LAN networks, cellphone users).

(v) Political factors: This features the environment policy, legislation trends, competition regulation, political stability, trade regulation, current or potential wars and conflicts and other political tendencies of instability that can engender fear of insecurity and appropriation.

Generally, the position of literature on software development are legend and can be summed up to include:

(i) The importance of human resources as a driving force and primary determinant of software development[13];

(ii) The influence of environmental factors such as policy regimes, competitive markets and institutional frameworks that promotes software development programmes and projects [7, 10, 11,16,19]

(iii) The pivotal role of inter-firm learning processes as an impetus that stimulate innovation activities in the industry $[3,2$, 21].

(iv) The crucial need for $\mathrm{R} \& \mathrm{D}$ and its significance as a critical factor that engender high quality software products with variety of products innovation, market innovation and organizational innovation [28].

Based on the foregoing, this study further revealed, the dearth of skilled professional/human resources relative to the quantum of needs in the industry and therefore a bane on software development in Nigeria. The issue of environmental factors such as institutional framework has been addressed by the Nigerian government with the establishment of Nigerian Communication Commission (NCC) vide Act No 75 of 1992 and National Institute for Information Technology Development Agency (NIITDA) vide Act 2007. These are the agencies that oversees the implementation of Information Communication Technology (ICT) policy regimes. To what extent these agencies have been effective in implementing the various ICT policies enunciated by Government have been studied separately. In [9], it was reported that the Nigerian Telecommunication policy has led to liberalization of Nigeria's telecommunication sector, competitive and widespread telecommunication services and high investment potentials. However, this has not translated into high quality of services (QoS) and consumer complaints are still prevalent. The reasons adduced were because the regulatory procedure seems to have performed averagely in terms of its objectivity, transparency, efficiency, professionalism and independence. Other banes reported in the study are factors such as inadequate infrastructure, socio-economic problems, and national security challenges. However, the aspects of share markets by indigenous software companies with its potential opportunities are still being threatened with uncontrollable importation of foreign software. And thus, make the Nigerian software industry highly risky and vulnerable [8].

\section{Research Methodology}

The study covered some selected software development firms, users and educational institutions in the six geopolitical zones of Nigeria. The seventy-five small, medium and large ICT firms (Lagos 70; Abuja 2; Port-Harcourt 2 and Kaduna 1) involved in software development and other ancillary firms published by Software Development Association in the Goldstar directories of 2007/2008 were purposively selected for the study. Data were collected using sets of questionnaire and from secondary sources. The questionnaire administered on software developers in select ICT firms elicited information on the influencing factors such as market environment, economics, patent, staff knowledge and skill, training and re-training programme, funding, among others. The questionnaire for educational institutions who are both developers and users covered Heads of Computer Departments of Polytechnics (5) and Universities (6) purposively sampled from the selected tertiary institutions involved with software development in Nigeria. Two hundred and fifty questionnaire were administered out of which 230 (92\%) were retrieved and 182 (79\%) found useful and analysed.Secondary data was collected from publications on the operations and competitiveness of software development in Nigeria. Descriptive and inferential statistics were employed for data analysis. Reliability and validity test were carried out and the results obtained from the test showed that all the items had an alpha above standard guideline of 0.70 . It implies that the scales are suitable for analysis with acceptable reliability. For the study, Cronbach's alpha score of 0.746 was obtained for the entire scale. This indicated that there was internal consistency of the entire variable scale as that variable construct enabled strong internal reliability. These results, therefore, confirmed that the instrument used for the study had satisfactory construct validity which included consistency [23].

\section{Results and DiscussionInternal Factors Influencing Software Development in Nigeria}

The factors influencing software development have been categorized into two. The internal factors include human resources, on the job training/retaining, research and development activities, ownership structure, availability of funds for training, and for Research and Development, working experience, licensing and linkages with other firms and size of firms. These factors were measured on Likert scale rating 5 to 1 . The results were obtained both inferentially using Analysis of Variance (ANOVA) and descriptively using Duncan Multiple Range (DMR) to obtain the relative weight (Mean Rating) of each variable. The descriptive statistics of the factors that influence software development were presented in Tables 5.1. The internal factors rated on a 5 point Likert scale (Table 5.2) showed the mean rank that include Human resources (3.69), on the job training (3.58), R\&D activities (3.48), working Experience (3.37), Ownership structures (3.31) and size of the firm (3.02). The result implies that 
on the average, none of the internal factors is without an influence even if it exists at a low level.

Similarly, and in order to affirm the relative strength index (RSI) of the variables in the internal factors influencing software development, their significance and relatedness of the Duncan Multiple Range (DMR) of the variables were further subjected to factorial ANOVA test (Table 5.2). These results further underscore the importance of collaboration; human resources, working experience and training

Table 1: External and Internal Factors Influencing Software development

( combined Descriptive Analysis)

\begin{tabular}{|c|c|c|c|c|c|}
\hline \multirow[t]{4}{*}{ Variables } & \multicolumn{5}{|c|}{ Responses of } \\
\hline & $\begin{array}{l}\text { Very } \\
\text { high } \\
\text { influ } \\
\text { ence }\end{array}$ & $\begin{array}{l}\text { High } \\
\text { influ } \\
\text { ence }\end{array}$ & $\begin{array}{l}\text { Mode } \\
\text { rate } \\
\text { influe } \\
\text { nce }\end{array}$ & $\begin{array}{l}\text { Littl } \\
\text { e } \\
\text { influ } \\
\text { ence }\end{array}$ & $\begin{array}{l}\text { No } \\
\text { influ } \\
\text { ence }\end{array}$ \\
\hline & Freq & Freq & Freq & Freq & Freq \\
\hline & $\%$ & $\%$ & $\%$ & $\%$ & $\%$ \\
\hline Human & 118 & 375 & 15 & 41 & 55 \\
\hline resource & 19.5 & 62.1 & 2.4 & 6.8 & 9.0 \\
\hline On the & 97 & 238 & 35 & 111 & 115 \\
\hline $\begin{array}{l}\text { job } \\
\text { training }\end{array}$ & 16.3 & 39.9 & 5.9 & 18.6 & 19.3 \\
\hline$R$ and $D$ & 52 & 208 & 91 & 137 & 92 \\
\hline activities & 9.0 & 35.9 & 15.7 & 23.6 & 15.9 \\
\hline Ownershi & 34 & 213 & 141 & 97 & 95 \\
\hline $\begin{array}{l}\text { p } \\
\text { structure }\end{array}$ & 5.9 & 36.7 & 24.3 & 16.7 & 16.4 \\
\hline Availabili & 30 & 59 & 304 & 126 & 81 \\
\hline $\begin{array}{l}\text { ty of } \\
\text { funds for } \\
\text { training }\end{array}$ & 5.0 & 9.8 & 50.7 & 21.0 & 13.5 \\
\hline Working & 39 & 117 & 161 & 147 & 136 \\
\hline $\begin{array}{l}\text { experienc } \\
\text { e }\end{array}$ & 6.5 & 19.5 & 26.8 & 24.5 & 22.7 \\
\hline $\begin{array}{l}\text { Licensing } \\
\text { and } \\
\text { linkages }\end{array}$ & $\begin{array}{c}74 \\
12.4\end{array}$ & $\begin{array}{r}183 \\
30.7\end{array}$ & $\begin{array}{c}84 \\
14.1\end{array}$ & $\begin{array}{c}124 \\
20.8\end{array}$ & $\begin{array}{c}128 \\
21.4\end{array}$ \\
\hline $\begin{array}{l}\text { Size of } \\
\text { the firms }\end{array}$ & $\begin{array}{c}81 \\
13.4\end{array}$ & $\begin{array}{l}240 \\
39.7\end{array}$ & $\begin{array}{l}121 \\
20.0\end{array}$ & $\begin{array}{c}89 \\
14.7\end{array}$ & $\begin{array}{c}73 \\
12.1\end{array}$ \\
\hline Competiti & 24 & 32 & 314 & 138 & 96 \\
\hline on & 4.0 & 5.3 & 52.0 & 22.8 & 15.9 \\
\hline Economic & 96 & 238 & 59 & 81 & 134 \\
\hline factor & 15.8 & 39.1 & 9.7 & 13.3 & 22.0 \\
\hline Governm & 41 & 99 & 209 & 107 & 144 \\
\hline $\begin{array}{l}\text { ent } \\
\text { support } \\
\text { and } \\
\text { policy }\end{array}$ & 6.8 & 16.5 & 34.8 & 17.8 & 24.0 \\
\hline Social & 46 & 155 & 230 & 80 & 78 \\
\hline factor & 7.8 & 26.3 & 39.0 & 13.6 & 13.2 \\
\hline Access to & 52 & 208 & 91 & 137 & 92 \\
\hline skills & 9.0 & 35.9 & 15.7 & 23.6 & 15.9 \\
\hline Access to & 34 & 213 & 141 & 97 & 95 \\
\hline $\begin{array}{l}\text { technical } \\
\text { informati } \\
\text { on and } \\
\text { support }\end{array}$ & 5.9 & 36.7 & 24.3 & 16.7 & 16.4 \\
\hline
\end{tabular}

Table 2: Internal Factors influencing Software Development in Nigerian ICT

Industry (Inferential Analysis)

\begin{tabular}{ll}
\hline Factors & Mean Rank \\
\hline Licensing and linkages & $4.43^{\mathrm{a}}$ \\
Human Resources & $3.69^{\mathrm{b}}$ \\
On the job training & $3.58^{\mathrm{b}}$ \\
R \& D Activities & $3.48^{\mathrm{b}}$ \\
Availability of funds for R \&D & $3.38^{\mathrm{bc}}$ \\
Working experience & $3.37^{\mathrm{bc}}$ \\
Availability of funds for training & $3.21^{\mathrm{bc}}$ \\
Ownership structure & $3.31^{\mathrm{bc}}$ \\
Size of firm & $3.02^{\mathrm{c}}$ \\
\hline
\end{tabular}

Source: Field Survey 2012

$\mathrm{a}, \mathrm{b}, \mathrm{c}$; Means with different superscripts are significantly different $(\mathrm{F}=8.60, \mathrm{P}<0.05)$

Key: No influence $=1$, Little influence $=2$, Moderate influence $=3$, High influence $=4$ and Very high influence $=5$

\section{External Factors Influencing Software Development in Nigeria.}

The external factors analyzed include competition, economic factor, government support and policy, social factor, access to skills from the market and access to technical information and support. The result of their descriptive statistics indicates that the average response ranges between "high influence" and "very high influence".

The external factors influencing software development are noted in Table 5.3. The factors using ANOVA and rated on a 5-point Likert scale include access to technical information and support (3.65), competition with international market (3.59), economic factors (3.46), access to professional skills from the Labour market (3.39), government support (3.35) and social factor (3.30). Most of the factors were rated above 3.0 indicating that their influences were relatively moderate. Similarly, there is no significant difference $(\mathrm{F}=1.24, \mathrm{p}<0.05)$ in the influence of these factors on software development. 
Table 3: External Factors affecting Software Development in Nigerian ICT industry (Inferential Analysis)

\begin{tabular}{ll}
\hline Factors & $\begin{array}{l}\text { Mean Rank } \\
\text { Access to technical information \& } \\
\text { support }\end{array}$ \\
$\begin{array}{l}\text { Competition with international market } \\
\text { Economic Factors }\end{array}$ & $3.59^{\mathrm{a}}$ \\
Access to Professional skills from the & $3.46^{\mathrm{a}}$ \\
labour market & \\
Government support policy & $3.39^{\mathrm{a}}$ \\
Social factor & $3.30^{\mathrm{a}}$ \\
\hline
\end{tabular}

Source: Field Survey 2012

a, b, c; Means with the same superscripts are not significantly different $(\mathrm{F}=1.24, \mathrm{P}<0.05)$

Key: No influence $=1$, Little influence $=2$, Moderate influence $=3$, High influence $=4$ and Very high influence $=5$

\section{Determining the Significance of the Internal Factors Influencing Software Development}

In order to ascertain the relative strength index (RSI) of each variable within the internal factors influencing software development beyond descriptive analysis, the analysis of variance (ANOVA) test was carried out. The result was presented in Table 5.4. The result showed that among the internal factors, human resources $(\mathrm{F}=6.144, \mathrm{p} \leq .013), \mathrm{R}$ and $\mathrm{D}$ activities $(\mathrm{F}=$ $6.141, \mathrm{p} \leq .014)$, Ownership structure $(\mathrm{F}=12.325, \mathrm{p} \leq .000)$, and working experience $(\mathrm{F}=39.150, \mathrm{p} \leq .000)$ are the statistically significant factors influencing software development in Nigeria. Other internal factors such as on the job training/retraining $(\mathrm{F}=1.978, \mathrm{p} \leq .160)$, licensing $(\mathrm{F}=0.032, \mathrm{p} \leq .858)$ and size of the firm $(\mathrm{F}=1.151, \mathrm{p} \leq .284)$ do not have significant influence on software development in Nigeria.

Table 4: Internal Factors influencing software development in Nigeria

\begin{tabular}{|c|c|c|c|c|c|c|c|c|c|}
\hline $\begin{array}{l}\mathbf{S} / \\
\mathbf{N}\end{array}$ & Influencing factors(Internal ) & $\begin{array}{l}\text { Mea } \\
\text { n } \\
\text { Squa } \\
\text { re }\end{array}$ & $\mathbf{F}$ & Sig- & $\begin{array}{l}\mathbf{S} \\
\end{array}$ & $\begin{array}{l}\text { elopment in Nigeria } \\
\text { External factors }\end{array}$ & \multirow{2}{*}{$\begin{array}{l}\text { Me } \\
\text { an } \\
\text { Sq } \\
\text { uar } \\
\text { e }\end{array}$} & \multirow[t]{2}{*}{$\mathbf{F}$} & \multirow[t]{2}{*}{ Sig } \\
\hline & & & & & & & & & \\
\hline I & Human resources & $\begin{array}{l}4.844 \\
.788\end{array}$ & 6.144 & .01 & $\mathbf{I}$ & Competition & $\begin{array}{l}247 \\
.64\end{array}$ & $\begin{array}{l}210 \\
.95\end{array}$ & $\begin{array}{l}0.0 \\
00^{*}\end{array}$ \\
\hline Ii & On the job training/retraining & $\begin{array}{l}4.844 \\
.788\end{array}$ & 1.978 & .16 & & & $\begin{array}{l}8 \\
1.1 \\
74\end{array}$ & 7 & \\
\hline Iii & $\mathrm{R}$ and $\mathrm{D}$ activities & $\begin{array}{l}12.05 \\
4 \\
1.963\end{array}$ & 6.141 & .01 & I & Economic factor & $\begin{array}{l}61 . \\
948 \\
1.4 \\
47\end{array}$ & $\begin{array}{l}42 . \\
805\end{array}$ & $\begin{array}{l}0.0 \\
00 *\end{array}$ \\
\hline $\mathbf{I v}$ & Ownership structure & $\begin{array}{l}19.28 \\
9 \\
1.565\end{array}$ & $\begin{array}{l}12.32 \\
5\end{array}$ & .00 & $\begin{array}{l}\text { I } \\
\text { ii }\end{array}$ & $\begin{array}{l}\text { Government support and } \\
\text { policy }\end{array}$ & $\begin{array}{l}0.1 \\
27\end{array}$ & $\begin{array}{l}0.0 \\
87\end{array}$ & $\begin{array}{l}0.7 \\
69\end{array}$ \\
\hline $\mathbf{V}$ & Availability of funds for R\&D & $\begin{array}{l}7.326 \\
1.740\end{array}$ & 4.211 & .04 & & & $\begin{array}{l}1.4 \\
63\end{array}$ & & \\
\hline
\end{tabular}

Source: Field survey, 2012 *Significant level at $5 \%$

This result affirmed the findings in the global software industry and these polls of scientific and technical labour remain ever attractive to computer software and information technology firms. Furthermore, there is no means that all developing countries have an education system capable of turning-out suitably high levels of semi-skilled software workers. Even in India, where training programmes are extensive, few colleges outside the main six institutes of technology can offer more than basic programming training [15]. This is a situation that is also synonymous with Nigeria [22].

VIII.

Determining the Significance of the External Factors Influencing Software Development

Among the external factors (Table 5.5), competition $(\mathrm{F}=210.957, \mathrm{p} \leq 0.000)$, economic factor $(\mathrm{F}=42.805, \mathrm{p} \leq 0.000)$, social factor $(\mathrm{F}=5.551, \mathrm{p} \leq 0.003)$, access to skill $(\mathrm{F}=26.458, \mathrm{p} \leq 0.000)$ and access to technical information and support $(\mathrm{F}=82.493, \mathrm{p} \leq 0.000)$ are the statistically significant factors at 5 percent significant level. However, government support and policy $(\mathrm{F}=0.087$, $\mathrm{p} \leq$ 0.769) had no statistically significant influence on software development in Nigeria.

Table 5: External Factors influencing software tevelopment in Nigeria

\begin{tabular}{lllll}
\hline Vi & Availability of funds for training & .447 & .305 & .581 \\
& & 1.465 & & \\
Vi & Working experience & 58.06 & 39.15 & $.000^{*}$ \\
$\mathbf{i}$ & & 6 & 0 & \\
& & 1.483 & & \\
$\mathbf{V i} \quad$ Licensing and linkages with other & .669 & .032 & .858 \\
ii $\quad$ firms & 20.74 & & \\
& & 9 & & \\
& & & & \\
Ix $\quad$ Size of the firm & 2.215 & 1.151 & .284 \\
& & 1.924 & &
\end{tabular}




\begin{tabular}{lllll}
\hline I & Social factor & 0.7 & 5.5 & 0.0 \\
$\mathbf{v}$ & & 12 & 51 & $03^{*}$ \\
& 1.2 & & \\
& 93 & &
\end{tabular}

V Access to professional 20. 26. 0.0 skills from labour market $527 \quad 458 \quad 00^{*}$

76

$\begin{array}{lllll}\text { V Access to technical } & 85 . & 82 . & 0.0 \\ \text { i } \quad \text { information and support } & 773 & 493 & 00 * \\ & & 1.0 & & \\ & & 40 & & \end{array}$

Source: Field survey, 2012

$*_{\text {- significant at } 5 \%}$

The result indicated the passive role of government in growing the software industry in Nigeria. The situation is not in conformity with some of the international best practices that engendered the Silicon Valley of USA and Software industries of Italy, Indian and other Asian tigers $[18,20]$.

\section{Conclusion}

From the study, it can be concluded that Nigerian software developers develop a good software. The study demonstrated that the quality of human resources, intensity of activities, skill and experiences of the workforce were significant internal factors that influenced the effectiveness of software development, while other contingencies such as on the job training/re-training, licensing and size of the firms did not have significant influence on software development in Nigeria. Furthermore, the study underscored the expected role of government which is currently lacking. This seems to have impacted negatively on the effective attraction of private sector investments in the software industry. Hence, the government's seemingly passive role has somehow stunted the growth and development of the software industry in Nigeria.

\section{Acknowledgment:}

The author of this paper hereby thanks the various sectors, companies and organizations that responded to the questionnaire. The assistance from the NIITDA were highly acknowledged.

\section{References}

Abran, A.; LaFramboise, L.; and Bourque, P (2000):“A Risk Assessment Method and Grid for Software Measurement Programs", Software Engineering Management Research Laboratory, 3 October, 2000.

Http://www.Irgl.uqam.ca/publications/pdf/271.pdf

Retrieved on November, 2009.

Akerele, W.O. (2003): Learning and Technological Knowledge Acquisition in Nigeria's Small and Medium Enterprises (a Case Study of Manufacturing Enterprises in Oyo State) Nigerian Institute of Social and Economic Research (NISER) Ibadan Monograph Series No. 7, 2001.

Akinbinu, A. (2001): Technological Learning in Nigeria Passenger Car Industry: An Assessment. Nigerian Institute of Social and Economic Research (NISER) Ibadan Monograph Series No. 12, 2003.
Anderson, E. E. (2005): "Managerial Consideration in Participative Design of MIS/DSS." Information and Management. 1985, Vol .9, pp. 201-207.

Animalu, A.O.E. (2002): 'Technology Policy and Funding in Nigeria' in Bonkat, B . N. and Dagogo-George, A. (Eds.), Science and Technology News: a quarterly Publication of the Federal Ministry of Science and Technology, Abuja. July-Sept. 2002, 40 - 45

Alic, J. A. (2005): "Technology in the service industries", International Journal of Technology Management 9 (1), pp. 1-14.

Bell, D (2008): Constructing Social Theory. Lanham, MD: Rowman \& Littlefield. ISBN 978-0742564282

Binuyo, G.O. (2012): Evaluation of Computer Software Development in Nigeria. PhD. Thesis (Unpublished)

Bolarinwa, L .O. (2013): Assessment of the Implementation of Nigeria's Telecommunications Policy, M.Sc. Thesis (Unpublished)

Doz, Y., Santos, J., and Williamson, P. (2001): 'How Companies Win in the Knowledge Economy' in From Global to Multinational. Harvard Business School Press, 01. Research Technology Management. March - April, 2002, 45, (2), 2-8.

Figueiredo, P.N. (2007): Technological Learning and Innovation in Developing Countries. Available at www.inderscience.com

/www.newsletter/2007/article_autumn2007.pdf

Hullet, D.T. (2001): "Key Characteristics of a Mature Risk Management Process", Fourth European Project Management Conference, PMI Europe 2001, 7 June 2001. Jacobs, G.; Macfarlane, R., and Asokan, N. (1999): Comprehensive Theory of Social Development. International Centre for Peace and Development. 2352 Stone house Drive, Napa, CA94558, USA.

Jones, C. (1998): "Determining Software schedules," Computer, February, pp. 73-75.

Kazmin, A. L. (2008): "Infosys Technologies profit more than doubled", Financial Times, 22 April 2008.

Lall, S. (2002): Explaining Industrial Success in Developing World. Ld'A-QEH Development Studies Working Paper No. 15 International Development Centre. Nicholas, J. M. (2001): Project Management for Business and Technology. Prentice-Hall, Inc., Upper Saddle River, New Jersey 07458.

OECD (2005): Organization for economic Co-operation and Development. The Measurement of Scientific and Technological activities Proposed Guidelines for Collecting and Interpreting Technological Innovation data Oslo Manual European Commission.

OECD (2007a): Science, Technology and Industry Scoreboard 2007, Innovation within Companies pp 34

OECD (2007b): Science, Technology and Industry Scoreboard 2007, Innovation and Economic Performance pp 35

Oyelaran-Oyeyinka, B.; Adelaja, M. and Abiola, B .O. (2007): Small and Medium Enterprise Clusters in Nigeria: Institutions Policies and support Systems.

Oyinlola, N.B. (2012): Assessment of the Development of Information and Communications Technology for Teaching in Colleges of Education in Southwestern Nigeria. M.Sc. Thesis (Unpublished).

Pallant, D.L. (2004): Four common misconceptions in exploratory factor analysis In Statistical and 
methodological myths and urban legends: Doctrine, verity and fable in the organizational and social sciences. Lance, Charles E. (Ed.); Vandenberg, Robert J. (Ed.). New York: Routledge. pp. 61-87.

Pressman, R. S. (1999): A Manager's Guide to Software Engineering, New York: MsGraw- Hill.

Schware, R. (2000): "Software Industry Entry Strategies for Developing Countries: A "Walking on Two Legs" Proposition", World Development, Vol. 20 No.2. pp. 143 - 164. Pergamon Press.

Steinmueller, W. E. (1999): "The US software industry: an analysis and interpretative history", in Mowery, D. C. (ed.). The International Computer Software Industry (Oxford: Oxford University Press)

Vigder, M.; Gentleman, M. and Dean, J. (2008): COTS Software Integration: State of the Art. Technical Report NRC No. 39190.

WAITRO (2007): (World Association of Industrial and Technology Research and Technological Research and Technology Organizations): Best Practices for the Management of Research and Technology Organizations. Danish Technological Institute, P.O. Box 141 DK - 2630 Taastrup, Denmark, 2007.

Whitten, N. (2005): Managing Software Development Projects, Second Edition, New York: John Wiley \& Sons, Inc. 
APPENDIX 1: Examples of Nigerian Indigenous Software Products and

their Uses

\begin{tabular}{|c|c|c|c|c|c|c|}
\hline $\mathrm{S} / \mathrm{N}$ & Name of Software & Uses & Developer & Users & $\begin{array}{l}\% \text { of uses/ } \\
\text { acceptability }\end{array}$ & Other Remark \\
\hline 1 & Text-to-email & $\begin{array}{l}\text { For forwarding sms to email } \\
\text { for user support }\end{array}$ & $\begin{array}{l}\text { Cadarview } \\
\text { communications } \\
\text { Ltd }\end{array}$ & $\begin{array}{l}\text { Ctt-Asstes } \\
\text { Nigeria }\end{array}$ & $40 \%$ & $\begin{array}{l}\text { Feedback system } \\
\text { for customer care } \\
\text { operator }\end{array}$ \\
\hline 2 & File Automation & $\begin{array}{l}\text { For collating reports from } \\
\text { different workstations over } \\
\text { the internet without human } \\
\text { interface }\end{array}$ & $\begin{array}{l}\text { Cadarview } \\
\text { Communication } \\
\text { Ltd }\end{array}$ & $\begin{array}{l}\text { Mediatrak } \\
\text { Ltd }\end{array}$ & $50 \%$ & $\begin{array}{l}\text { For collation of } \\
\text { reports within the } \\
\text { workstation }\end{array}$ \\
\hline 3 & $\begin{array}{l}\text { PZMU (Please to } \\
\text { meet you) }\end{array}$ & $\begin{array}{l}\text { A social marketing solution } \\
\text { that uses people's location to } \\
\text { present their needs and also } \\
\text { who is ready to solve them }\end{array}$ & IQube Labs & Public use & $70 \%$ & $\begin{array}{l}\text { Social marketing } \\
\text { tool/solution }\end{array}$ \\
\hline 4 & SMS Blaster & $\begin{array}{l}\text { This is a solution for sending } \\
\text { SMS to uses people's location } \\
\text { to present them needs and } \\
\text { who is ready to solve them }\end{array}$ & $\begin{array}{l}\text { Cadarview } \\
\text { Communication } \\
\text { Ltd }\end{array}$ & $\begin{array}{l}\text { Energy } \\
\text { Bank Ghana }\end{array}$ & $80 \%$ & $\begin{array}{l}\text { Integrated } \\
\text { to the } \\
\text { system }\end{array}$ \\
\hline 5 & Visitors' logger & $\begin{array}{l}\text { A solution used for taking } \\
\text { inventory of visitors by } \\
\text { capturing images and } \\
\text { biometric information }\end{array}$ & CHAMS & CHAMS & $100 \%$ & $\begin{array}{l}\text { For security and } \\
\text { keeping records of } \\
\text { visitors }\end{array}$ \\
\hline 6 & IED & $\begin{array}{l}\text { Data collection for residents } \\
\text { of a state }\end{array}$ & CHAMS Ltd & Osun State & $60 \%$ & $\begin{array}{lr}\begin{array}{l}\text { Still } \\
\text { development }\end{array} & \text { under } \\
\text { modules) } & \text { (In }\end{array}$ \\
\hline 7 & AKOWE & $\begin{array}{l}\text { An online teaching tool, that } \\
\text { assist lecturers deliver their } \\
\text { lectures over the internet } \\
\text { realtime using video, voice, } \\
\text { writing and text } \\
\text { functionalities }\end{array}$ & $\begin{array}{l}\text { OAU ICT } \\
\text { Developers }\end{array}$ & OAU & $80 \%$ & $\begin{array}{l}\text { A Consultant was } \\
\text { sent from Australia } \\
\text { to train the OAU } \\
\text { developers team on } \\
\text { the development of } \\
\text { standard software }\end{array}$ \\
\hline
\end{tabular}

which are critical factors that greatly influence the successes of the Asian Tigers and Silicon Valley (OECD, 2007a). 